\title{
Castoriadis' Concept of Institution and Democracy
}

\author{
by Jacob Dahl Rendtorff
}

\section{Introduction}

How can we conceive change of values and institutionalization of new organizational values and cultures? What is the basis of change in society? These problems of change, values and institutions are addressed in many different ways in institutional theory. However, we often feel the need for further conceptual clarification. We find this clarification in the work of the Greek and French philosopher and social theorist Cornelius Castoriadis (1922-1997) who can be said to offer a presentation of the social theory of institutions in order to show its significance for present concepts of politics and building of novel institutions.

Castoriadis argues that humanity attempts to come to autonomic self-expression through imagination as a primary force of history. The social imaginary is a dream of human autonomic emancipation and self-expression. Social institutionalization is a product of this social imaginary. I would argue that we can apply Castoriadis' concept of institutionalization to the process of search for the legitimacy of society and we may say that we experience a process of search for autonomy and self-limitation within the creations of new meanings of democratic institutions.

For Castoriadis this theory of imaginary institutionalization is the basis for a theory of democracy, because democratic policy is based on an ongoing search for autonomy and critical questioning of existing social institutions. Direct democracy is created in an open process of creation, but also in the capacity for self-limitation and wise and prudent decision-making. The ethos of democracy is an understanding of the limits of human existence and action. It is only by this understanding of self-limitation that we can understand the conditions of human autonomy and democracy.

With this in mind we can apply Castoriadis' concept of institutionalization to the process of search for legitimacy of different kinds of institutions and organisations and we may say that we experience a process of search for autonomy and selflimitation within the creations of new meanings of institutions through democratic politics. This may be the reason why ethics and values are so important for creation of new understandings and meanings of modern society.

\section{Castoriadis' critique of bureaucracy}

The point of departure of the social thought of Castoriadis is a critical investigation of the phenomena of institutions in Eastern Europe. Like other Marxist French thinkers like Althusser, Castoriadis wants to give a scientific explanation of the contribution of Marxism to social organization. Like Sartre and Althusser, Castoriadis can be said to be oriented towards reinventing Marx as a social theorist and to determine the Marxist contribution to social philosophy. At the same time Castoriadis develops his own political and social philosophy in his late work, which is inspired by socialism, 
but also contains many new and interesting perspectives on social theory that in many ways are deeply critical towards the Marxist paradigm.

Castoriadis presents an anti-authoritarian and autonomy-based democratic theory of society. His basic idea is that human beings can come to free autonomous selfrealization without being governed by work leaders, priests, therapists, politicians or generals coming from the outside and wanting to determine their actions. Human fantasy and dreaming of autonomy is the primary force in history, which is neither determined by predestination or by reason. Castoriadis' philosophy about social fantasy and about imaginary institutions of society therefore derived considerable significations from the riots of the French youth in 1968 Paris.

Castoriadis, who originally was educated in economics and law, had emigrated to France in 1945 thanks to a scholarship, after having fought as a Greek Trotskyist against the Stalinist Greek communist party. Castoriadis had grown up in a Greek society marked by civil war and totalitarian regimes. In Paris, he contributed to create the French section of the Fourth International in 1945 and was later a member of the committee directing the popular French review Socialisme ou Barbarie, which became a pivotal socialist review in the 1960 s and played a significant role vis-à-vis the 1968 riots. Simultaneously with his intellectual activities, he was employed as an economist by OECD, which gave him great opportunities to investigate the capitalist structures of society. In 1974 he opened a clinic for psychoanalysis and in 1979 he became Directeur d'Études on the famous research institution in Paris École des Hautes Études en Sciences Sociales.

In his articles in Socialisme ou Barbarie Castoriadis criticized both capitalist and communist bureaucratic and totalitarian societies. Western states displayed a very undemocratic co-operation between the State and private companies, and in reality it was the owners of capital who had the power to decide over the economy. But Castoriadis was also critical towards the turn that the dictatorship of the proletariat had had in Soviet Union. In 1948 he disagreed with the Trotskyites, because they defended the USSR, and he believed in autonomous self-organisation outside the dominant bureaucratic State. He was therefore also critical towards Sartre's defence of communism and he is told to have said that Sartre was wrong at the right time, to which Sartre replied that Castoriadis was right at the wrong time.

Castoriadis develops in $L a$ société bureaucratique his central notions about bureaucratic capitalism. Such a society is fundamentally separated into classes and is characterized by strong hierarchical structures and strong separations between those who give orders and those who execute them. Bureaucratic capitalism consists of great industrial complexes based on advanced technologies. The dominating rationality is goal-oriented, utility-oriented and instrumental. In many cases chiefs, work leaders and superiors can use their positions of power and give irrational, inhuman, and half-sadistic orders to workers that break with the logic of production. To change this situation workers have no other choice than organizing themselves in autonomous groups of resistance.

Castoriadis argues that the State-capitalistic society of the communist bloc has become a regime that is as inhuman as the capitalist society of the West. Communist institutions had forgotten human beings. The Stalinist society indicates that a specific group of leaders had taken over the power. Stalin's totalitarian State is considered by Castoriadis to be a reified bureaucracy, where the party had taken over power in 
society and in which historical development had stopped. Accordingly, Castoriadis thought that there was no big difference between capitalist structures of repression and the kind of exploitation of workers and peasants that was the consequence of the victory of the proletariat in the Soviet Union. That sort of communist society can be characterised as bureaucratic monopolistic capitalism. There, Marxism was used as ideology to oppress the Proletariat, which had not been liberated but exposed to a new kind of oppression.

Eventually, Castoriadis had to recognize the limitations of Marxism. He was sceptical towards the metaphysical theory of Marx about the surplus value in the last book of the Capital and he wanted to give up dogmatic Marxist philosophy of history. At the same time he had to admit that the development in Eastern Europe had reduced Marxism to a bureaucratic ideology. Russian society had been established upon the false ideology of the worker's State, whereby the dominant group in society succeeded in preserving its power. The relations of production of the USSR did not lead to inequality, but separated the population in proletariat and bureaucrats of the party. Soviet relations of production implied exploitation of workers and therefore these relations of production were not essentially different from capitalism. Factories were not democratically governed, but dependent on a huge bureaucratic machine that governed workers with terrorist reason.

Therefore, it was possible to describe the government of the Soviet Union as bureaucratic capitalism based on the hierarchic structures of government in factories. As such, we cannot either say that communist regimes in China or Eastern Europe were more developed. In all these societies it was possible to describe a new type of bureaucratic capitalism that was based on bureaucratic organisations of power like the army, the public companies or the party. Castoriadis' criticism of the communist party would lead eventually to a generalised theory about bureaucratic forms of organization in modern late capitalism and technology-dependent society.

\section{Towards a theory of democracy}

After the Soviet Union was more and more criticized, Castoriadis realized that he had to choose between orthodox Marxism and revolution. During the 1960 s he understood that new autonomous groups, groups of young people, the woman's liberation movement and other groups were seeking alternative life forms and that they expressed a new form of criticism of bureaucratic capitalism. At the same time he was very critical towards Althusser's structural Marxism, which did not contain any conception of human self-creation. In a book on Marxism and revolutionary theory (1964-65) Castoriadis had therefore chosen the revolutionary project that he stated was an integrated part of the human dream of being different. In order to overcome finitude, alienation and reification, human beings wish to create new imaginary social institutions. The oppressed will overcome the goal-rationality in the technical and bureaucratic structures and fantasy become the driving force of history. That was the reason why the ideas of Socialisme ou Barbarie, even though the publication of the review stopped in 1967, had great significance for the riots of 1968 . The leader of the Nanterre riot Daniel Cohen-Bendit was connected to the review and even though Castoriadis held a low profile during the riot of 1968, his ideas of selfgovernance and autonomy in universities and work environments were conceived as important demands by the revolutionary student movement. Later, in 1981, 
Castoriadis also published a book together with Cohen-Bendit concerning autonomy and ecology.

After he left OECD, Castoriadis concentrated the rest of his life on developing his social and historical theory about a democracy based on autonomy and on the human imaginary creations and socially instituting forces. What is imaginary is not a picture of anything. It is not socially or physically predetermined. It is only on the basis of the human imaginary process of creation that something is realized. The creative force of fantasy expresses an ability, on the basis of hope and desire, to get a better social reality and create new social institutions. This ability is not predetermined by the gods, nature or rationality. The major work L'institution imaginaire de la société (The imaginary institution of society) describes an alternative autonomy-based theory of democracy. Society is in its ontology--its being poiesis--determined by the imaginary force of creation of humanity. This is the basis for the analysis of the history of idea of fantasy and it shows how the philosophical tradition has a tendency to ignore the psychological and social significance of fantasy.

In the development of this alternative social theory Castoriadis refers to the psychoanalysis of Freud that is used to overcome an individualistic reading of social theory. Castoriadis argues that the human psyche is a nomad that in the end can never be fully socialized, but has an anti-social core, which at the same time represents the foundation for the capacity of humanity to institute an imaginary and real social change. In his use of psychoanalysis Castoriadis is very critical towards the announcements of Lacan and Foucault of the death of the subject and of the ideas that the unconscious structures have taken over in relation to the conscious ego or I. Instead we have to understand how the psychoanalysis of the human fantasies can help to achieve a better understanding of the unconscious and imaginary. Psychoanalysis helps us to understand ourselves, without implying that we are determined by our unconscious life.

In contrast to the structuralist and therapeutic reading of the psychoanalytic project, Castoriadis emphasizes that psychoanalysis must be conceived as a modern narrative of the classical demand "know thy self" originating from ancient Greek philosophy and culture, which is mediated through tragedy and the Greek epic stories by Homer and others. Psychoanalysis is a kind of Catharsis that helps us to understand our identity through the analysis of unconscious fantasies.

Through this conception of human beings. Castoriadis argues that the real contradiction is not between individual and society, but instead that society and psyche are different poles that cannot be reduced to one another. The original psychical pole cannot in itself produce social significance and meaning. Rather, the social fantasies are created in the surrounding society. The socially imaginary significances are at the same time different from both the rational and the real forces that are realized in this society. In this way one can define a special social imaginary, a characteristic ability to institutionalize new social structures and relations. The characteristic socially instituting ability of the imaginary is breaking both with functionalism and structuralism by contributing to the creation of a more original kind of being that can be characterized as a self-instituting and self-creating unit that cannot be reduced to the physical, the biological or the psychological. The social institutions will be able to carry a number of socially imaginary significances with this creating force. It is this significance that contributes to the creation of the social 
significances of the institutions and keeps a given society alive. Because of the selfcreation of society this significance becomes a part of the collective meaning of society. This meaning can be said to be based on either open or closed autonomy. The primitive or totalitarian society is in this context building a predetermined social order, whilst the democratic society builds on an open and autonomic process of creation.

This conception of the instituting function of imagination is developed in L'institution imaginaire de la société and in the numerous collection of articles Les carrefours $d u$ labyrinthe $I-V$. In his investigation of the history of ideas of fantasy and imagination, Castoriadis states that this creative force has been partly forgotten by the philosophical tradition. Already the classical definition of Aristotle in $D e$ Anima expresses the lack of understanding of the imaginary and creative force of fantasy. In the philosophy of Aristotle it is defined as a non-real mimesis and a passive negativity and it is not really clear how fantasy can be defined as the mediation between emotion and rationality. If we look at the philosophy of Kant, we can also see that he has not been enough conscious of the importance of fantasy, because he has not let the transcendental imagination have great significance in the second edition of the second edition of the Kritik der reinen Vernunft. All the time Freud spoke about fantasy, yet he never analyzed the imaginary as that which creates unconscious fantasies and gives being to the non-existent.

\section{A new theory of democracy}

The starting point for the notion of democracy for Castoriadis is the relation between politics and philosophy in classical Greece. Philosophy expresses the imaginary institutionalization of society, because it questions all the time the existing social institutions. It is developed in close relation to democratic politics and thereby it contributes actively to the change of society of its own institutions.

Accordingly, both philosophy and politics are closely connected to the development of the autonomy of the citizens. Political philosophy is asking the question of the validity of the fundamental norms of society. In the development of history there are many examples of this fight for the imaginary institutionalization of the autonomy of the citizens. Castoriadis mentions the struggle of the bourgeoisie against the church and the king, the American and the French revolutions, and the fight for freedom of workers, women and youth movements in the Western societies as expressions of this fight for the political and philosophical autonomy in the imaginary institutionalizations of society.

However, the emergence of democracy in classical Greece becomes, according to Castoriadis, the most perfect expression of the imaginary institutionalization of society. Castoriadis says that the political institutions of classical Greece are based on a direct democracy where every citizen with autonomy takes part in the democratic process of decision-making. The Greek city-states were characterized by autonomy and openness. The laws of democracy, the public rules and the shared values are institutionalized in an open process of creation where the citizens can always ask for the meaning and validity of the institutions of society. In this sense democratic society emerges as an auto-institutionalization of the norms of society. In a democratic society citizens contribute collectively to make their own laws. They engage in the process for the sake of justice and the common good and to bring order 
in the existing chaos. In the Greek city-state the people (demos) were considered as the absolute sovereign and this creates an autonomous political space, the public space that is the basis for the institutionalization of the laws in society.

With classical Greece playing as counterpart, the representative democracy of our days cannot really be determined as anything other than a "liberal oligarchy", where the few are taking part directly in the process of decision-making, while the many remain submitted to the bureaucratic structures. Castoriadis did not have much respect for the development of the globalized economy of the 1990s, which he regarded as based on undemocratic structures.

Castoriadis places his theory about the imaginary institutionalization in L'institution imaginaire de la société, adding to it the perspective of an ethics of self-limitation. Humility and self-limitation are central notions for democratic self-understanding. If the community is supposed to maintain its norms, it cannot show hybris in relation to those norms. Castoriadis mentions the tragedy by Sophocles entitled Antigone. In this tragedy, both Antigone and Kreon are confronted with the power of human passions and they have to control themselves not to end in a tragic series of actions and events, which they eventually fail to do. According to Castoriadis, the art of selfcontrol is closely connected to an understanding of the mortality and finitude of humanity, which are the real background of the possibility of any autonomy and democracy. In this context, what matters most is to make art and philosophy a form of social life. The ethos of democracy is based on an understanding of the limits of human actions and of the impossibility of the total comprehension of the consequences of the actions. Democracy has a comprehension of the tragic aspects of human existence. It is based on the understanding of the fact that a totalitarian regime always implies hybris in relation to the finitude of human nature. The limitations of democracy are neither based on what is necessary nor on what is contingent, but on human creativity aware of the possibilities and limitations of human action. This is related to the respect for freedom. Only by the understanding of human mortality can we respect ourselves and others as autonomic and free human beings and at the same time aim at realizing ourselves in an autonomic and self-organizing society.

This approach to Greek democracy is further developed in Castoriadis' lectures on democracy in Ancient Greece, La cité et les lois. Ce qui fait la Grèce, 2, Séminaires 1983-1994. La creation humaine 3. In those seminars Castoriadis developed his investigations of institutionalization in Greek democracy. In particular, he was interested in the issue of how a society questions its own institutions and how this society contributes to its own institutionalizations. In ancient Greece it was important to ensure positive freedom in the city-state. The radical spirit of imagination became the basis for auto-creation of society and the human effort of self-creation in this society. In Greek democracy human beings create themselves and their essence is self-creation. Virtues of democracy are deliberation and prudence. The direct democracy in ancient Greece can be promoted as a model for the modern world and individual freedom in democracy. The polis of self-realization is conceived as a society of free citizens who are going to realize the social imaginary in the political process of self-realization. The social imaginary is realized in the classical political space, the agora, where citizens meet in the political community to discuss the future of society. Here, we have the democratic creation where all citizens are free and their 
freedom is realized in the polis. In this sense, we can talk about autoinstitutionalization of society, where sovereign citizens create the political community and the political collectivity together in the political process.

The democratic process of society is in this sense conceived as a process of selfinstituting or self-institutionalization where community is a result of a historical creation. Here, we observe great resemblances between Castoriadis and Hannah Arendt, whom Castoriadis recognizes as an important source of inspiration for his political philosophy. The social imaginary of democracy is the source of representative government and this is also based on the sources of civil society. In this context Castoriadis emphasizes the institutional elements of modern democracy and he also says that polis in human creation is the result of such autoinstitutionalization. In the polis the citizens are in contrast to the sphere of oikos, characterized by mutual friendship (philia). The political relation is conceived as a relation between friends and this is the foundation of the vision of the common happiness in politics. Castoriadis conceives the act of instituting in democracy as a kind of "Grundnorm" in the Kelsian sense, in the way that it is the foundation of the institutionalization of society. In addition, inspired by Hannah Arendt, Castoriadis uses the Greek imaginations of mimesis, mythos and catharsis as the foundation of tragedy. In particular, the tension between Hybris and Nemesis was very important, because what is stated is the concept of the Greek tragedy as basis for the act of creation of democracy.

In contrast to bureaucratic organization of reified institutions with strict separation of groups and classes and with strong hierarchical structures based on instrumental and utility-oriented rationality, the imaginary search for autonomy is characterized by a strife for autonomy and emancipation like the one represented by new social groups and their reaction against established social structures. According to Castoriadis, we have to conceive human revolutionary projects as an effort to be emancipated from bureaucratic structures in an imaginary creation of autonomous democratic institutions. The social imaginary is not a picture of anything. It is not predetermined, but it expresses a capacity to create upon hopes and desires for a better social reality and new social institutions.

Castoriadis defines this concept of institutionalization in his L'institution imaginaire de la société as the foundation of a theory of democracy: History is therefore understood as creation (poiesis), i.e. it is determined by the human imaginary capacity of creation. Society is created through an imaginary symbolism based on conceptions of meaning and values that are the basis for social existence. We can talk about a social capacity of imagination, which represents a capacity to imagine and thereby contributes to the creation of new social structures and contexts. The human imaginary capacity of creation can be characterized as a primordial kind of being that contributes to the creation of common imaginary contexts of significance as the basis for community and collective meaning. This horizon of meaning can be based on a more less open autonomy, dependant on democratic or totalitarian forms of organization.

\section{References:}

Cornelius Castoriadis: La société bureaucratique (Paris, 1973). 


\section{Nordicum-Mediterraneum}

Cornelius Castoriadis: L’institution imaginaire de la société (Paris, 1975)

Cornelius Castoriadis: Les carrefours du labyrinthe I-V (Paris, 1978)

Cornelius Castoriadis, La cité et les lois. Ce qui fait la Grèce, 2. Séminaires 19831984. La création humaine III (Paris, 2008).

Jacob Dahl Rendtorff is Professor of Ethics at the Department of Communication, Business and Information Technologies, Roskilde University, Denmark. He is Head of Studies and Head of Research. Rendtorff has been visiting researcher in Utrecht, Freiburg, Rome, Boston and Santa Clara University, California. Rendtorff is responsible for educational programs in business and public relations. Rendtorff has published books and articles on phenomenology and hermenetics, political theory and philosophy of law, organisation theory, management and business ethics, bioethics and law and other subjects. 